\title{
MODEL PENGELOLAAN PROGRAM PENDIDIKAN ANAK USIA DINI DI TK ISLAM AN NUR KOTA PEKANBARU
}

\author{
Wasiah Sufi ${ }^{1}$, Sean Marta Efastri ${ }^{2}$ \\ Universitas Lancang Kuning \\ Email : wasiah.sufi@unilak.ac.id ${ }^{1}$, seanmarta@unilak.ac.id ${ }^{2}$
}

\begin{abstract}
Abstrak
Penelitian ini bertujuan untuk menganalisis model pengelolaan program pendidikan anak usia dini yang meliputi planning, organizing, actuating, Controling dan Evaluating. Penelitian ini menggunakan metode deskriptif Kualitatif. Teknik pengumpulan data yang digunakan adalah observasi, wawancara dan dokumentasi. Hasil penelitian menunjukan pengelolaan program pendidikan anak usia dini di Tk Islam Annur sudah berjalan baik di lihat dari prestasi peserta didik yang banyak dan membanggakan, namun masih belum optimal dikarenakan masih ada beberapa guru yang tingkat pendidikannya belum sesuai dengan aturan yaitu memiliki tingkat Akademik Sarjana Pendidikan Anak Usia Dini. Hal yang menghabat dalam proses pengelolaan PAUD diantaranya pada Sub organizing masih lemah, dilihat dari biaya yang masih di pungut pada kegiatan tambahan seperti program karya wisata anak didik.
\end{abstract}

Kata Kunci: Model Pengelolaan, Pendidikan Anak Usia Dini

\begin{abstract}
This study aims to analyze the management model of Early Childhood Education programs which include planning, organizing, actuating, controlling and evaluating. This study used descriptive qualitative method. Data collection techniques used were observation, interviews and documentation. The results showed the management of early childhood education programs in Annur Islamic Kindergarten had gone well in view of the achievements of many and proud students, but it was still not optimal because there were still a number of teachers whose educational levels were not in accordance with the rules of having a Academic Degree in Children's Education Early age. The thing that holds up in the PAUD management process, among others, in the sub-organizing is still weak, seen from the costs that are still levied on additional activities such as student tourism program.
\end{abstract}

Keywords: Management Model, early chilhood education.

(C) 2019 Wasiah Sufi ${ }^{1}$, Sean Marta Efastri ${ }^{2}$ Under the license CC BY-SA 4.0

http://jurnal.upmk.ac.id/index.php/pelitapaud 


\section{PENDAHULUAN}

Pendidikan merupakan upaya untuk mengembangkan kemampuan dan menggali potensi seseorang untuk dengan layak baik secara pribadi maupun sebagai anggota masyarakat. Pendidikan adalah proses sosialisasi untuk mencapai kompetensi pribadi dan sosial sebagai dasar untuk mengembangkan potensi dirinya sesuai dengan kapasitas yang dimiliki. Pendidikan bertujuan untuk mendewasakan anak, kedewasaan tersebut mencakup kedewasaan intelektual , emosional,sosial, dan moral tidak sematamata kedewasaan dalam arti fisik saja.

Anak usia dini merupakan periode awal dan mendasar dalam pertumbuhan dan perkembangan kehidupan manusia. Pendidikan Anak Usia Dini sangat penting. Karena kapabilitas kecerdasan orang dewasa terjadi ketika anak berusia 4 Tahun dan terjadi perkembangan yang sangat cepat tentang jaringan otak ketika anak berumur 8 tahun dan akan mencapai puncak kecerdasan pada anak berusia 18 Tahun. Masa perkembangan kecerdasan anak tersebut dinamakan masa golden age. Masa emas ini hanya datang sekali, maka apabila masa ini terlewatkan berarti habislah kesempatannya.
Dalam UU Sisdiknas Nomor 20 tahun 2003, pasal 1 butir 14, PAUD adalah suatu upaya pembinaan yang ditujukan kepada anak sejak lahir sampai dengan usia 6 tahun yang dilakukan melalui pemberian rangsangan pendidikan untuk membantu pertumbuhan dan perkembangan jasmani dan rohani agar anak memiliki kesiapan dalam memasuki pendidikan lebih lanjut. Untuk itulah suatu lingkungan dan keluarga seharusnya mampu memberikan fungsi pengasuhan, kasih sayang dan dukungan kepada anak.

Saat ini Provinsi Riau berdasarkan data referensi kementerian pendidikan dan kebudayaan 2019 tercatat memiliki 5.256 PAUD yang aktif. Untuk Kota Pekanbaru berjumlah 769 PAUD. Berdasarkan SK Penetapan BAN PAUD dan PNF, Nomor: 146/BAN PAUD DAN PNF/AKR/2018, Tahap III Tahun 2018. Menetapkan ada beberapa Pendidikan Anak Usia Dini (Paud/TK) di Kota Pekanbaru yang meraih Akreditasi A. diataranya, $\mathrm{Kb}$ Darma Yudha, TK An Nur, TK Dharma Loka 1, TK Insan Utama, TK Islam Asy Syams, TK Daniel HKBP, TK Dharma Bunda, TK Santa Maria, TK Future Islamic School.

Taman Kanak-Kanak (TK) Islam An-Nur merupakan suatu wadah 
Pendidikan Anak Usia Dini dalam membina Anak untuk mempersiapkan pendidikan kejenjang Sekolah Dasar dan mempunyai model atau pola pengelolaan yang baik didalamnya sehingga mampu menjadikan anak berprestasi. Dari 9 TK Berakreditasi A dipekanbaru, TK AN Nur Pekanbaru, merupakan sekolah islam tertua berdiri sejak tanggal 16 Juli 2007, dengan No izin operasional : 420/PP.4/XI/2008/9047, 13-11-2008 yang berada di lingkungan Masjid Agung AnNur Provinsi Riau Jl Hang Tuah di bawah pengelolaan Badan Pengelola Masjid Agung An-Nur Divisi Tarbiyah dan dikepalai oleh Ka Bid Pendidikan Formal.

Pada saat peneliti melakukan observasi lapangan Di TK AnNur Pekanbaru melihat ada beberapa keistimewaan yang ditonjolkan pada paud tersebut, diantaranya yaitu pengelolaan yang dikelola oleh tenaga pendidik yang secara akademik belum semua memiliki standard kualifikasi akademik ijazah sarjana atau Diploma empat (D4), tetapi mampu mengelola TK Annur sesuai dengan kurikulum yang ditetapkan dan terpenting mampu membimbing menjadi anak yang berprestasi.

Terbukti ketika TK An Nur mampu bersaing dalam beberapa perlombaan tingkat Kelurahan, Kecamatan dan Provinsi selalu mendapatkan juara. Dengan Pengelolaan yang baik tidak hanya dapat membimbing anak berprestasi saja, melainkan akan berdampak baik pada akreditasi sekolah dan jumlah anak pada setiap tahunnya akan terus meningkat. Serta TK AnNur juga menawarkan pembelajaran yang bermuatan keagamaan.

Berdasarkan latar belakang di atas penulis tertarik untuk meneliti TK Annur yang berada di Kota Pekanbaru dengan judul Model Pengelolaan Pendidikan Anak Usia Dini di TK An Nur Kota Pekanbaru. Peneliti tertarik untuk melihat lebih dalam bagaimana pola pengelolaan yang ada di TK Islam An Nur sehingga TK tersebut dapat membimbing anak hingga berprestasi.

Menurut Rusdiana $(2015: 13)$ berpendapat bahwa manajemen berasal dari bahasa Inggris, yaitu to manage, yang berarti mengatur, mengelola, melaksanakan dan memperlakukan. Jadi, manajemen sama artinya dengan pengelolaan dan begitu juga sebaliknya. Pendapat George R. Terry yang dikutip oleh Rusdiana mendefinisikan manajemen merupakan proses khas yang terdiri atas tindakan-tindakan perencanaan, pengorganisasian, pelaksanaan, dan 
pengawasan serta penilaian yang dilakukan untuk menentukan serta mencapai sasaran yang telah ditetapkan melalui sumber daya manusia dan sumber lainya.

Pengelolaan disini sama halnya dengan manajemen, jadi manajemen Pendidikan Anak Usia Dini (PAUD) adalah suatu upaya mengelola, mengatur, dan mengarahkan proses interaksi edukatif antara anak didik dan guru serta lingkungan secara teratur, terencana, dan tersistematisasi untuk mencapai tujuan lembaga Pendidikan Anak Usia Dini (PAUD). Dengan kata lain, pola pengelolaan pendidikan anak usia dini (PAUD) adalah suatu model atau rancangan yang di gunakan sebuah lembaga pendidikan untuk mengelola pendidikan anak usia dini guna meningkatkan perkembangan anak untuk mempersiapkan kejenjang yang lebih lanjut. Berdasarkan Fungsi manajeman (pengelolaan) bahwa tahapan-tahapan dalam manajemen pengelolaan PAUD meliputi: Perencanaan, pengorganisasian, pelaksanaan dan pengawasan.

\section{METODE PENELITIAN}

Penelitian ini dilakukan di Taman Kanak-Kanan Islam An Nur Kota
Pekanbaru, Tujuan dilakukan penelitian ini yaitu untuk mengetahui dan menjadikan Model Percontohan pengelolaan bagi Paud yang belum meraih akreditasi A. Jenis penelitian ini menggunakan penelitian kualitatif. Jenis penelitian ini menggunakan penelitian kualitatif. Yang menjadi informan dalam penelitian ini adalah Kepala Sekolah, Guru TK, Staf administrasi dan Wali murid. Adapun teknik pengumpulan data pada penelitian ini yaitu observasi, wawancara dan dokumentasi. Seluruh data yang didapat akan dianalisis dengan menggunakan metode kualitatif melalui interpretasi etik dan emik. Analisis data dengan menggunakan etik dan emik ini adalah dengan mengklasifikasikannya ke dalam dua bagian, yaitu data etik (dari teori) dan data emik (dari temuan di lapangan).

\section{HASIL PENELITIAN DAN \\ PEMBAHASAN}

Pengelolaan Program Pendidikan Anak Usia Dini pada TK AN NUR Kota Pekanbaru

Dalam bab ini penulis akan mengemukakan tentang uraian hasil yang diperoleh dari penelitian dilapangan. Dengan melakukan analisis sehingga dapat 
menjawab permasalahan- permasalahan

penelitian yang dilakukan dalam

pengelolaan program PAUD. Hasil wawancara yang dilakukan peneliti dengan key informan kepada TK An Nur dan tenaga pendidik sebagai berikut:

\section{Perencanaan Pengelolaan Program Pendidikan Anak Usia Dini}

Perencanaan merupakan suatu
kegiatan yang sangat mendasar dalam
suatu pengelolaan, mulai dari apa yang
ingin dicapai, bagaimanan cara mencapai,
berapa lama direncakanan, berapa biaya
yang di perlukan berapa orang yang
melaksanakan dan siapa yang melakukan.
Perencanaan dibuat sebelum tindakan
dilakukan. Perencanaan yang dilakukan di
TK Annur sudah berdasarkan persetujuan
dengan Ketua Yayasan dan sesuai dengan
kurikulum yang digunakan mulai dari
materi pembelajaran, waktu yang akan
dilaksanakan, dan peralatan yang diperlukan untuk kelancaran proses belajar mengajar.

Setiap guru sebelum melakukan proses belajar mengajar harus menyiapkan dokumen perencanaan yaitu Perencanaan Program Semester (Prosem), Rencana Pelaksanaan Pembelajaran mingguan (RPPM), dan Rencana Pelaksanaan
Pembelajaran Harian (RPPH), hal ini diharapkan mampu mengembangkan dan melaksanakan kegiatan pembelajaran yang sesuai dengan karakteristik, kebutuhan dan perkembangan peserta didik.

Perencanaan dilakukan disetiap kegiatan selalu melibatkan walimurid, guru dan kepala sekolah, sehingga komunikasi terjalin dengan baik, mulai dari biaya kegiatan selalu di infokan jauh sebelum kegiatan dilaksanakan, sehingga kami wali murid dapat menyiapkan dan tujuan dapat tercapai. Dalam waktu dekat TK Islam Annur merencanakan untuk menambah kegiatan ekstrakulikuler bermain alat musik anglung, kegiatan ekstrakulikulir ini belum ada di lakukan di sekolah PAUD lain yang ada di Pekanbaru.

Dari hasil wawancara peneliti, perencanaan pengelolaan program pendidikan anak usia dini di TK An Nur sudah di buat dan dilakukan dengan baik seperti adanya perencanaan kegiatan pembelajaran, kegiatan ekstrakulikuler, kerjasama dengan wali murid, dan sebagainya.

\section{Pengorganisasian Program Pendidikan} Anak Usia Dini

Pengorganisasian merupakan kegiatan pengelompokan atau pembagian 
program-program kgiatan yang ada di Tk An Nur Pekanbaru. Menurut Mulyasa (2014) menjelaskan agar pembelajaran PAUD dapat dilaksanakan secara optimal perlu di organisasikan dan di kelola sedemikian rupa. Sedikitnya terdapat empat hal yang perlu diperhatikan berkaitan dengan organisasi dan manajemen pembelajaran PAUD, yaitu pelaksanaan pembelajaran, pengadaan dan pembinaan tenaga ahli, pendayagunaan lingkungan sebagai sumber belajar, serta pengembangan dan penataan kebijakan.

Hasil dari pengamatan peneliti di lapangan terkait pengeorganisasian di TK Islam AN Nur memiliki dua bagian program pelaksanaan pembelajaran yaitu Program Pembelajaran Kelompok A dan Kelompok B. Kategori kelompok A merupakan anak-anak yang berusia empat Tahun kebawah dengan metode pembelajaran yang bersifat membantu pertumbuhan dan perkembangan anak misalnya, pendidik memberikan gambar kepada peserta didik dan kemudian mewarnai gambar tersebut. Selain itu peserta didik diajarkan berdoa, bernyanyi dan hapalan surah pendek. Sedangkan kategori Kelompok B merupakan anakanak berusia empat tahun keatas. Dengan menekankan pengenalan huruf dan angka kepada peserta didik, selain itu juga sudah mulai mengejah tulisan sedikit demi sedikit diberikan untuk memberikan dasar pengetahuan sebelum memasuki jenjang pendidikan sekolah Dasar. Pengenalan bahasa inggris juga sudah diberikan kepada peserta didik selain bahasa Indonesia dan bahasa arab.

Dalam pengamatan peneliti, terdapat juga program kesehatan anak yang bekerja sama dengan puskesmas kelurahan sumahilang kota Pekanbaru dalam memberikan penyuluhan kepada anakanak TK seperti menimbang berat badan, memberikan vitamin serta memperhatikan tingkat perkembangan kemajuan fisik anak. Hal ini bertujuan agar anak-anak sehat jasmani dan siap mengikuti belajar mengajar di sekolah.

Dalam hal pengorganisasian tenaga ahli di bidang PAUD dapat dikatakan belum sesuai dengan dengan spesialisasi akademik yang dimiliki oleh TK Islam An Nur, dikarenakan masih banyak guru-guru PAUD yang tidak memiliki dasar Pendidikan Keilmuan Pendidikan Anak Usia Dini dan Psikologi melainkan sarjana Pendidikan agama bahkan masih banyak yang belum sarjana. 
Pelaksanaan Program Pendidikan Anak

\section{Usia Dini}

Pelaksanaan merupakan suatu tindakan kegiatan yang mengusahakan atas perencanaan dan pengorganisasian sebelumnya yang telah dilakukan. Mendorong dan mengupayakan kepada kelompok organisasi untuk saling bekerja sama dalam mencapai sasaran dan tujuan yang sudah ditetapkan sebelumnya. Ada beberapa rencana yang sudah dipersiapkan oleh TK Islam Annur dalam melakukan pelaksanaannya pada tahun ajaran 20182019, harapannya yaitu anak dapat memahami atas materi-materi yang telah dipersiapkan oleh TK Annur. Metode pembelajaran yang digunakan dalam memberikan materi pembelajaran harus disesuaikan dengan situasi dan kondisi, yaitu yang menggunakan alat atau bendabenda yang bervariasi, sehingga metode yang digunakan oleh guru bisa menarik perhatian anak-anak untuk lebih memperhatikan kegiatan belajar dan mudah untuk dipahami pastinya.

Berdasarkan hasil pengamatan yang dilakukan di TK Annur dalam pelaksanaannya memiliki beberapa program pengajaran, diantaranya yaitu:

TK Islam Annur memakai Kurikulum K13 yang sudah diintegrasikan dengan GBBP Departemen Agama. Program tambahan, iqra, praktek shalat setiap jum'at, hafalan surat pendek dan ayat pilihan, hafalan do'a harian, peragaan menasik haji, mengadakan atau mengikuti perlombaan hari besar nasional dan harihari besar islam, baik yang diadakan sekolah maupun pihak luar, khatam alqur'an bagi yang mampu, pentas seni akhir tahun, dan pengenalan bahasa inggris.

Ekstrakurikuler menggambar mewarnai, menari. drum band, tahfiz, rebana, dakwah dan alat musik angklung.

Berdasarkan pengamatan yang dilakukan tentang program pengajaran yang dilakukan TK Annur dalam pelaksanaannya, pendidik telah menggunakan beberapa alat pengajaran serta metode-metode yang digunakan dalam menyampaikan materi, sehingga hal tersebut tidak membuat jenuh peserta didik bahkan yang ada adalah memberi semangat kepada peserta didik dalam memperhatikan materi yang disampaikan.

Selain itu kegiatan proses belajar mengajar diberikan program tambahan yang dilakukan rutin setiap tahun yakni Peragaan Menasik Haji. Kegiatan ini diharapkan mampu menambah pengetahuan peserta didik tentang rukun 
islam yang ke-5 yaitu Naik haji bagi yang mampu.

Dalam kegiatan belajar mengajar menggunakan alat serta metode yang beragam agar anak tidak mudah bosan, biasanya juga menggunakan metode bercerita, memberi tanya jawab, menyanyi, memperagakan sebuah keterampilan dan dalam memberikan penilaian kepada murid dengan cara memberikan tanda dari bintang 1 sampai bintang 5. Dengan demikian diharapkan akan memacu anak lebih giat lagi untuk belajar, hal ini dilakukan karena pada dasarnya anak usia dini senang bermain dan hal-hal baru.

Untuk mengasah kemampuan siswa siswi rutin mengikutsertakan murid-murid yang memiliki bakatnya untuk menuangkan kemampuannya mengikuti perlombaan pada hari besar nasional dan hari-hari besar Islam, baik yang diadakan sekolah maupun pihak luar, sehingga juga memotivasi murid-murid lain untuk saling berlomba menuangkan bakatnya masingmasing.

Dapat disimpulkan bahwa bermain bagi anak usia dini dapat belajar dari banyak hal, bersosialisasi, menempatkan diri, mangatur emosi, toleransi, kerja sama dan banyak hal lainnya. Disisi lain dengan bermain juga dapat mengembangkan kecerdasan mental, spiritual, bahasa dan keterampilan motorik anak usia dini. Oleh karena itu bagi anak usia dini tiada hari tanpa bermain.

\section{Pengawasan Pengelolaan Program Pendidikan Anak Usia Dini}

Pengawasan merupakan suatu proses dalam menetapkan ukuran kinerja dan pengambilan tindakan yang dapat mendukung pencapaian hasil yang diharapkan sesuai dengan kinerja yang telah ditetapkan sebelumnya.

Menurut Kepala Sekolah TK Annur, dalam kegiatan pengawasan di Tk Annur adalah dengan memantau semua kegiatankegiatan yang dilaksanakan di sekolah. Seperti kegiatan pembelajaran, kegiatan hafalan, dan kegiatan lainnya.

Pengawasan di TK Annur dilakukan secara langsung oleh Kepala Sekolah yang juga diikuti oleh Ketua Yayasan Annur. Untuk pengawasan yang dilakukan oleh Kepala Sekolah dimulai dengan mengunjungi kelas belajar, memperhatikan kegiatan pembelajaran yang berlangsung, dan menanyakan kegiatan-kegiatan yang dilaksanakan di TK Annur. Kegiatan pengawasan tersebut dilakukan rutin per tiga bulan sekali, sedangkan Pengawasan yang dilakukan 
oleh Yayasan yaitu dengan melakukan pengawasan langsung dan pngawasan tidak langsung. Untuk pengawasan langsung sama dengan yang dilakukan oleh Kepala Sekolah yakni sedemikian halnya tadi, sementara pengawasan tidak langsung yaitu dengan meminta laporan kepada Kepala Sekolah berupa laporan tertulis yang berisikan kegiatan pembelajaran, kegiatan hafalan dan kegiatan lainnya, hal ini dilakukan rutin per semester atau per 6 bulan sekali”.

Dapat disimpulkan bahwa pengawasan yang dilakukan di TK Annur yaitu dilakukan secara langsung oleh Kepala Sekolah per 3 bulan sekali dan Ketua Yayasan per semester atau per 6 bulan sekali. Pengawasan merupakan suatu kegiatan yang harus dilakukan, karena dengan adanya pengawasan dapat mengukur kegiatan yang dilaksanakan apakah sudah sesuai dengan perencanaan yang dibuat sebelumnya. Hal ini dilakukan apabila terjadi kesalahan dapat di atasi langsung agar tidak menimbulkan permasalahan baru.

\section{Evaluasi Program Pendidikan Anak}

\section{Usia Dini}

Evaluasi atau yang biasa disebut dengan Pengukuran, yang berarti menilai tetapi dilakukan dengan mengukur terlebih dahulu. Evaluasi juga merupakan sebuah proses pengumpulan data untuk menentukan sejauh mana, dalam hal apa, dan bagaimana tujuan pendidikan sudah tercapai, bagaimana yang belum dan apa sebabnya.

Evaluasi dapat dilakukan dengan beragam cara diantaranya yaitu melalui pengamatan. Pengamatan dilakukan dengan mengamati perkembangan seluruh stakeholder mulai dari evaluasi kegiatan pembelajaran yang berlangsung, pengawasan rutin yang dilakukan, evaluasi tenaga pendidik hingga perkembangan dan sikap anak didik.

Setelah dilakukan evaluasi, TK Annur masih memiliki kelemahan, yakni dalam segi hal tenaga pendidiknya. Masih kurangnya tenaga pendidik dibidang akademik PAUD dan Psikolog. Untuk tenaga pendidik berjumlah 25 orang, lebih dari setengah jumlah tersebut tenaga pendidik belum memiliki kualifikasi dibidang akademik pendidikan anak usia dini dan psikolog, hal ini menyebabkan tenaga pendidik harus menyesuaikan sebelum mengajar.

Dapat disimpulkan bahwa tenaga pendidik yang ada di TK Annur masih ada yang belum mempunyai kualifikasi dibidang akademik pendidikan anak usia 
dini dan psikolog khusunya, sebab salah satu penunjang dari program pendidikan anak usia dini adalah terpenuhinya tenaga pendidik pada bidang yang memiliki lulusan akademik PAUD dan Psikolog. Setelah dilakukannya evaluasi ditemukan keganjalan mengapa TK Annur bisa mendapatkan akreditas A dan tetap eksis pada saat ini dimana jika dilihat saingannya yang sangat banyak.

\section{Hambatan dalam Pengelolaan Program Pendidikan Anak Usia Dini di TK An Nur}

Kurangnya tenaga pendidik di bidang akademik dan psikolog. Berdasarkan Peraturan Menteri Pendidikan Nasional No.16 Tahun 2007 Tentang Standar Kualifikasi Akademik dan Kompetensi Guru beserta lampirannya menyebutkan : Guru PAUD harus memiliki Kualifikasi akademik minimum Diploma Empat (D-IV) atau Sarjana (strata 1) dalam bidang pendidikan anak usia dini atau Psikologi yang diperoleh dari program studi terakreditasi.

Untuk tenaga pendidik di TK An Nur berjumlah 25 orang guru, namun yang memiliki kualifikasi akademik Sarjana Pendidikan PAUD hanya 12 orang guru, selebihnya masih ahli madya (D-3), dan saya sendiri juga masih ahli madya.
Harapan untuk kedepannya guru-guru dapat melanjutkan pendidikan sarjana pendidikan Paud sesuai kualifikasi dalam peraturan. Disini kami juga membutuhkan tenaga psikolog untuk membantu perkembangan kebutuhan anak.

Dari penjelasan diatas bahwa tenaga pendidik di TK An Nur Kota Pekanbaru belum semua memiliki Kualifikasi di bidang akademik Pendidikan anak usia dini dan belum memiliki psikolog. Salah satu kelancaran program pendidikan anak usia dini adalah terpenuhinya tenaga pendidik pada bidang yang mempunyai kualifikasi lulusan pendidikan anak usia dini. Selain belum terpenuhinya kualifikasi tenaga pendidik di TK An Nur tamatan s1 paud tetapi masih banyaknya berlatar belakang s1 non paud. Kurangnya biaya dalam kegiatan wisata. Dalam pengamatan peneliti terdapat juga program karya wisata kepada anak didik di ikuti seluruh peserta didik hal ini bertujuan untuk pengenalan lingkungan dan dunia luar kepada anak dengan metode belajar karya wisata dapat memudahkan penerimaan anak dalam menerima materi juga menghilangkan kejenuhan anak sebab anak umumnya menyukai hal hal baru, anak usia dini rasa ingin tahunya yang begitu besar sehingga metode belajar 
karya wisata sangat tepat untuk dilakukan sebagai pembelajaran. Dapat disimpulkan bahwa program kegiatan wisata anak masih dipungut biaya untuk transportasi dan makan bagi peserta didik. Umumnya ekonomi orangtua wali murid yang anaknya bersekolah di TK Islam Annur dalam kategori ekonomi rendah.

\section{SIMPULAN}

Perencanaan dilakukan terlebih dahulu sebelum melakukan kegiatan dan Program PAUD yang ada di Tk An Nur selalu melibatkan seluruh aspek yang ada di sekolah tersebut, mulai dari pengurus yayasan, kepala paud, guru dan wali murid.

Pengorganisasian di TK Islam An Nur sudah terlaksana dengan baik sesuai dengan visi dan misi yang telah ditentukan. Namun pembagian tugas masih belum sesuai dengan yang direncanakan. Hal ini di sebabkan tingkat pendidikan akademik para pendidik masih banyak yang tidak linear diluar bidang keilmuan PAUD serta kurangnya koordinasi di dalam organisasi, dapat dilihat dari kurang komunikatifnya pimpinan atau kepala sekolah TK Islam An Nur.

Pelaksanaan program pendidikan Anak usia dini di Tk Islam An Nur sudah terlaksana dengan baik, dapat dilihat dari proses belajar sesuai deng RPPH yang dibuat oleh pendidik dan kurikulum PAUD terbaru. Dapat dilihat juga dari prestasi piagam penghargaan yang di raih peserta didik di Kota Pekanbaru sehingga mereka dapat bersaing dan unggul untuk melanjutkan pendidikan ke jenjang Sekolah Dasar.

Dalam pengawasan telah dilakukan setiap harinya oleh Kepala Sekolah Tk Islam Annur sebagai pengawas Inti kegiatan apapun dalam pengelolaan Paud serta berkomunikasi kepada anggotanya selaku guru-guru PAUD jika terjadi permasalahan langsung dapat di tindak lanjuti secepatnya.

Selain pengawasan juga dilakukan evaluasi kepada guru dan murid. Evaluasi kepada guru dapat dilihat dari kelengkapan dalam mempersiapkan recana pembelajaran setiap semester. Sedangkan evaluasi kepada murid dilakukan dengan melihat tingkat kemajuan anak mulai dari program pendidikan anak usia dini yaitu dengan mencatat perkembangan dan kemajuan anak di portofolio. Selain itu metode penilaian dilihat melalui pemberian tugas kepada anak didik, keaktifan anak dan hasil karya anak. 
Hambatan dalam pengelolaan program Pendidikan Anak Usia Dini di Kota Pekanbaru adalah lulusan akademik pendidik yang belum memenuhi bidang pendidikan anak usia dini dan psikologi. Adanya tekanan dari orangtua kepada peserta didik, terkait hal program kegiatan karya wisata yang membutuhkan dana tambahan sehingga memberatkan.

\section{DAFTAR PUSTAKA}

Kamus Besar Bahasa Indonesia, "Pengertian Pengelolaan", (2015). http://kamus bahasa indonesia.org /polapengelolaan /mirip [3 November2015].

Kurniadin, Didin dan Imam Machali, (2012). Manajemen Pendidikan Konsep\&Prinsip Pengelolaan Pendidikan, Yogyakarta: Ar-Ruzz Media,.

Kusbudiah, Yayah, "Pengelolaan Pembelajaran Di RA/ TK/ PAUD Sebagai Upaya Mengoptimalkan Pencapaian Perkembangan Anak Usia Dini. (2015). http://bdkbandung.kemenag.go.id/jurnal /276 [11 November 2015].

Latif, Mukhtar, dkk, Orientasi Baru Pendidikan Anak Usia Dini Teori dan Aplikasi, (2014). Jakarta: Kencana Prenademedia Group,.

Matinis dkk, Panduan Pendidikan anak usia dini PAUD. (2010). Gaung Persada Press Jakarta
Moeslichatoen. (2004). metode pengajaran di Taman Kanak Kanak, Jakarta: PT Asdi Mahasatya.

Mulyasa, E. (2014). Manajemen PAUD. Bandung: PT Remaja Rosdakarya,

Mursid, Pengembangan Pembelajaran PAUD. (2017). Bandung: PT Remaja Rosdakarya.

Mustari, Muhamad. (2014). Manajemen Pendidikan, Depok: PT Raja Grafindo Persada,

Nurani Sujiono, Yuliani, (2011). Konsep Dasar Pendidikan Anak Usia Dini, Jakarta: PT Indeks.

Rusdiana, Pengelolaan Pendidikan. (2015). Bandung: Pustaka Setia.

Republik Indonesia. (1945). Undang-undang Dasar 1945 Tentang Pembukaan. Lembar Negara RI Tahun 1945.

Sugiyono, Metode Penelitian Pendidikan Pendekatan Kuantitatif, Kualitatif, R\&D. (2013). Bandung: Alfabeta,.

Sekretariat Negara. Jakarta. Republik Indonesia. (2002). Undang-undang No 23 Tentang Perlindungan Anak. Lembar Negara RI Tahun 2002. Sekretariat Negara. Jakarta. Republik Indonesia. 2003.

Undang-undang No 20 Tentang Sistem Pendidikan Nasional. Lembar Negara RI Tahun 2003. (2005). Sekretariat Negara. Jakarta. Republik Indonesia.. 